\title{
Environmental Dilemma of Humic Substances: Being Adsorbents and Being Carcinogens
}

\author{
E. Yel and G. Ahmetli
}

\begin{abstract}
Humic materials can be classified as soluble in high pH, soluble in all pH's, and insoluble in all pH's (IHA). In this study, humic substances in the environment were discussed, and their different environmental contributions, either positive or negative, were investigated. Some humic substances help the water treatment while some others cause carcinogenic matter accumulation in water. This dilemma was discussed with different examples. In the first part of this study, IHA was used as adsorbent in removal of some metals, chemical oxygen demand (COD) and color from water. The results were presented together with literature results. IHA could adsorb various heavy metals in 10 to $300 \mathrm{mg} / \mathrm{g}$ capacity interval, while COD removal performance was $2270 \mathrm{mg} / \mathrm{g}$. In the second part of the study, soluble humic matter in natural waters and disinfection by-products (DBP) formation upon chlorination of such waters were discussed. Humic fractions were important precusors of DBP's such as trihalomethanes (THMs) and haloacetic acids (HAAs). Depending on the water resource, the humic substances, THM and HAA formation potentials and types and quantities of the compounds may differ, but all are bioaccumulative and potentially carcinogenic. The study investigated the two different faces of humic substances in the environment.
\end{abstract}

Index Terms-Adsorption, disinfection by-product, humic acid, treatment.

\section{INTRODUCTION}

Constituting approximately $65-75 \%$ of the total organic substance in the soil, humic substances are comprised as a result of natural disintegration. They are significant components of soil. They can be found not only in soil, but also in natural waters, river, lake and sea bottom sediments as well as other chemical and biological transformation materials, and even in lignite and coal with oxidized bitumen. With a high molecular weight, despite their variable nature regarding atomic charge, they generally carry negative charge. While existing in soluble fraction (HA) in alkali solutions, some may be insoluble within acidic solutions. Their elementary compositions vary based on their origins and preparation conditions.

Humic substances contain high levels of carbon; and aromatic rings and alkyl chains including a great variety of functional groups (carboxylic and phenolic groups, $-\mathrm{COOH}$, $-\mathrm{OH},-\mathrm{NH}_{2}$ etc.) as their fundamental units. Those functional groups have a highly reactive capacity to compete and to

Manuscript received March 26, 2014; revised May 20, 2014

Esra Yel is with the Selcuk University, Engineering Faculty, Environmental Eng. Department, Konya, Turkey (e-mail: etarlan@selcuk.edu.tr).

Gulnare Ahmetli is with Selcuk University, Engineering Faculty, Chemical Eng. Department, Konya, Turkey (e-mail: ahmetli@selcuk.edu.tr). create a complex [1], thus, with this feature; they play a key role in aquatic transformation, transportation, disaggregation and bioactivity of metals [2], [3].

The free radicals which are formed as a result of humic acid-metal interaction have a significant role in creation of metal complexes, bonding of heavy metals, pesticides and herbicides, inactivation of microbial enzymes, hence in environmental detoxification [4]. This ability to create complexes derives from the anionic polyelectrolyte characteristic of their structure [5].

Humic acids play quite opposite parts in environmental issues due to their structural differences and resolution characteristics. There are humic forms which contribute to the creation of pollution and/or hazardous compounds, while some of the humic substances are useful in removal. This study aims to explain this contradiction using different examples.

\section{MATERIAL AND METHOD}

Dissolved and undissolved forms of humic acids have two different roles in environmental aspect. This study discusses the both situations.

\section{A. Humic Acids as Adsorbents in Treatment}

Adsorption is an important application for separating dissolved metals from the environment. Various studies have shown that insoluble humic acids (IHA) obtained from coal are efficient in adsorption as well as common adsorbents such as active carbon, clay etc. Depending on the origin of the coal, the performance of every IHA sample as an adsorbent may vary, since the structure of humic acid also changes. Some of many studies on IHA and metal adsorption are selected to present primarily, considering the metal bonding characteristic of humic acid. The results of the experimental studies which have been performed with IHA which was synthesized from Konya lignite in laboratory conditions shall be evaluated along with the others. The IHA has been synthesized from 2 different kinds of lignite from Konya region (Beysehir and Ermenek), using the method presented in the previous studies [6]. Heavy metal adsorption tests on IHA samples are performed in batch reactor systems. $0.1 \mathrm{~g}$ IHA sample has been added to synthetic solutions of different metals, and shaken on $220 \mathrm{rpm}$ to ensure IHA contacts with the solution. The metal concentration has been followed with time. The adsorption capacities have been calculated using the equilibrium concentrations. The efficiency of IHAs in the removal of other important pollution indicators, color and organic matter (COD), has also been demonstrated. This information, when evaluated alongside with other studies on adsorption using IHAs 
obtained from different types of coal, propounds that IHA may be employed as adsorbent in treatment.

\section{B. Humic Acids as Potentially Hazardous Substances on Drinking Water Supply}

Surface waters contain natural organic materials (NOM) which are formed as a result of natural decompositions in the ecosystem. Structure and amount of these materials may vary between the sources. Natural organic materials have a potential to transform into hazardous disinfection by-products (DBP) in consequence of chlorination which is a common method of disinfection in drinking water supply. The most common of those products are trihalomethanes (THM), haloacetic acids (HAA) and haloacetonitriles (HAN) [7]. Each of these groups contains different number of components. Within chlorinated water, the type and the amount of these components depend on season, geographical position, the amount and the structure of the natural organic material, bromide concentration, $\mathrm{pH}$, temperature, NOM characteristics and amount, chlorine/bromine rate, SUVA254 etc [8]. Within natural material structure, fulvic and humic fractions are the ones which contribute to the creation of THM most.

It was after the presentation of DBP formation in the literature that those parameters took place in drinking water standards of many developed countries in the world, even the first limit values have been decreased in time. Yet, the issue has taken place in Turkish legislation very recently.

In the second half of this study, characteristics and detrimental effects of NOMs and the factors that affect their formation shall be discussed as well as the literature information about drinking water limit values in Turkey and in the world.

\section{ADSORPTION WITH HUMIC ACIDS}

\section{A. Adsorption onto IHA}

There are many studies about the adsorption of different parameters, such as radioactive materials, organic materials and especially metals, onto IHA which is obtained from soil or various kinds of coal. Some of these shall be discussed in the forthcoming parts. Within the scope of this study, $\mathrm{Cr}, \mathrm{Zn}$, $\mathrm{Cu}, \mathrm{Mn}$ and $\mathrm{Fe}$ adsorption from aqueous solutions onto IHA has been demonstrated, using low quality lignite with extended reserve from Konya-Beysehir and Karaman-Ermenek regions to synthesize the IHA with the method explained in previous studies [6] (Fig. 1).
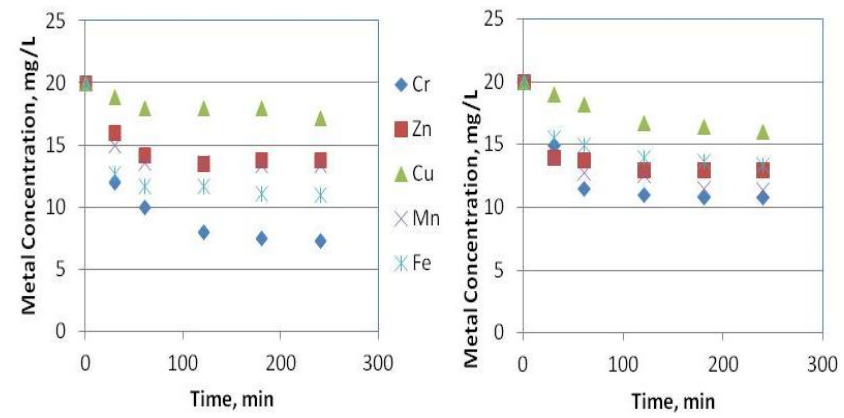

Fig. 1. The change of the residual concentration during $\mathrm{Cr}, \mathrm{Zn}, \mathrm{Cu}, \mathrm{Mn}$ ve $\mathrm{Fe}$ adsorption onto (a) Beysehir IHA (BIHA) and (b) Ermenek IHA (EIHA).

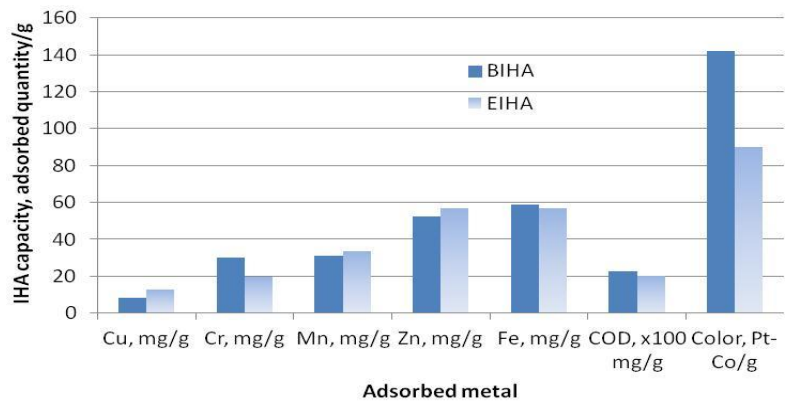

Fig. 2. Comparison of metal, COD and color adsorption capacities of Humic acids.

In the study performed with the initial concentration of $20 \mathrm{mg} / \mathrm{L}$, the system has reached the balance between the first 60-120 minutes for all the metals, and no significant metal removal has been observed after that period. It is possible to say that IHA samples have not been highly successful to remove those metals, but still there have been some decreases in metal concentrations.

Fig. 2 shows the comparison of metal, organic material and color removal capacities of two humic acids. Their performances are approximate. IHAs were more successful in color and COD removal than metal removal. In general, 2040-2270 mg/g COD removal and 90-144 Pt-Co/g color removal can be considered as high capacities indicating that these IHA samples can be successively used even in treatment of high COD and high color industrial wastewater. This adsorption kinetic has been analyzed in another study [9]. The main goal in this part of the study is to determine the environmentally useful characteristic and usage of humic acid (IHA) which is insoluble. The adsorbent usage of IHA shall be demonstrated, evaluating the experimental findings together with the studies in the literature performed for different IHA samples as indicated in Table I. The table is a short review of the studies performed with IHAs of various origins, and indicates that, performances vary with the origin of the IHA and adsorbed matter onto it.

\section{B. Another Role of Humic Acid in Adsorption}

Metal binding properties of humic acid affects the adsorption performance when it is present in the medium where other adsorbents are adsorbing metals. Three ways of the effects of humic acids in such systems were reported, either positive or negative [18]. As the first effect, metal-humic acid complexes that are not adsorbable are formed. In the second effect humic acid directly bonds onto adsorbent surface and metal adsorption reduces as a result of blocking the adsorption sites on the surface. Whereas in the third effect humic acid forms a bridge between metal and the adsorbent surface, and so increases the adsorption performance [19].

Lai et al., [18] obtained an adsorbent by covering the goethite onto sand particles and and studied the effects of humic acid on $\mathrm{Cd}$ adsorption. They found that the addition of humic acid before and after $\mathrm{Cd}$ changed the $\mathrm{Cd}$ adsorption performance differently. Some studies reported that adsorption capacities of the clays modified with humic acids increased [20], [21]. Adsorption of $\mathrm{Cu}, \mathrm{Cd}$ and $\mathrm{Cr}$ onto $\mathrm{Ca}$-montmorillonite modified with humic acid is higher than non-modified clay, as humic acid changes the adsorption 
sites onto the surface and so changing the adsorption mechanism and increasing the capacity [20].

\section{Potential Humic Acid HaZard in Drinking Water}

Humic matter content of the surface water is the most contributing factor of DBP formation in drinking water disinfection. Humic matter copmposed of humic and fulvic acids, concentrations of which depends upon the location of water resource, natural vegetation around it, presence of algae and the season of the year [22]. Number of studies have been performed on the DBP formation as a result of reactions of humic and fulvic acids with chlorine [23], [24]. The two common types of DBP's are THM and HAA compounds, they have serious adverse effects on human and environmental health such as cancer as a result of bioaccumulation [25], [26]. Table II indicates some common DBP types and their health effects [27]. Their cancer risks are critical and treatment systems need to be modified to prevent such risks [28].

TABLE I: EXAMPLES OF AdSORPTION STUdies PERFORMED By HuMiC ACIDS

\begin{tabular}{|c|c|c|c|}
\hline Adsorbent & Studied Metals & Result & Reference \\
\hline $\begin{array}{l}\text { Raw and } 100-300^{\circ} \mathrm{C} \\
\text { processed coal }\end{array}$ & $\begin{array}{l}\mathrm{Li}, \mathrm{K}, \mathrm{Ca}, \mathrm{Mg}, \mathrm{Ni}, \mathrm{Co}, \mathrm{Ba}, \mathrm{Fe}, \\
\mathrm{Zn} \text { (with and without alcohol) }\end{array}$ & Alcohol increased $\mathrm{Ni}$ and Co adsorption & $\begin{array}{l}\text { Murakami et al, } 1997 \\
{[10]}\end{array}$ \\
\hline $\begin{array}{l}\text { Humic acids with the } \\
\mathrm{COOH} \text { groups }\end{array}$ & $\mathrm{Cu}, \mathrm{Pb}, \mathrm{Mn}, \mathrm{Cd}$ & $\mathrm{Cu}>\mathrm{Pb}>\mathrm{Mn}=\mathrm{Cd}$ & Manunza et al, 1995 [11] \\
\hline $\begin{array}{l}\text { North-Bohemia coal Humic } \\
\text { Acid }\end{array}$ & $\mathrm{Cu}, \mathrm{Pb}, \mathrm{Zn}, \mathrm{Ni}, \mathrm{Cd}, \mathrm{Ca}, \mathrm{Mg}$ & $0.50,0.59,0.18,0.12,0.16,0.1,0.03 \mathrm{mmol} / \mathrm{g}$ & $\begin{array}{l}\text { Madronova et al, } 2001 \\
\text { [12] }\end{array}$ \\
\hline Humic Acid & $\begin{array}{l}\mathrm{Pb}, \mathrm{Ag}, \mathrm{Hg}, \mathrm{Cd}, \mathrm{Ba}, \mathrm{Cu}, \mathrm{Ni}, \mathrm{Co} \\
\quad \mathrm{Mn}, \mathrm{Zn}, \mathrm{Ca}, \mathrm{Mg}, \mathrm{V}, \mathrm{Al}, \mathrm{Cr}\end{array}$ & $\begin{array}{c}\mathrm{Pb}>\mathrm{Ag}=\mathrm{Hg}>\mathrm{Cd}=\mathrm{Ba}=\mathrm{Cu}>\mathrm{Ni}= \\
\mathrm{Co}=\mathrm{Mn}=\mathrm{Zn}=\mathrm{Ca}>\mathrm{Mg}=\mathrm{V}=\mathrm{Al}=\mathrm{Cr}\end{array}$ & $\begin{array}{l}\text { Martyniuk and } \\
\text { Wieckowska, } 2003 \text { [13] }\end{array}$ \\
\hline $\begin{array}{l}\text { Beysehir and } \\
\text { Ermenek lignite IHA }\end{array}$ & $\mathrm{Fe}(\mathrm{II})$ & $\begin{array}{c}59 \mathrm{mg} / \mathrm{g}(1.06 \mathrm{mmol} / \mathrm{g}) \text { for Beysehir IHA } \\
\text { and } \\
57 \mathrm{mg} / \mathrm{g}(1.02 \mathrm{mmol} / \mathrm{g}) \text { for Ermenek IHA }\end{array}$ & $\begin{array}{c}\text { Tarlan and Ahmetli, } 2007 \\
{[6]}\end{array}$ \\
\hline Humic Acid & $\mathrm{Al}$ & acidity, ionic strength, temperature and $\mathrm{pH}$ were effective & Wang et al, 2007 [14] \\
\hline $\begin{array}{l}\text { Stockton Mine coal Humic } \\
\text { Acid }\end{array}$ & $\begin{array}{l}\mathrm{Zn}, \mathrm{Cu} \text {, and } \mathrm{Cd} \text { in Acid Mine } \\
\text { Drainage (AMD) }\end{array}$ & $\begin{array}{l}\text { for } \mathrm{Ca}(\mathrm{OH})_{2} \text { neutralised } \mathrm{AMD} \text {, addition of lignite } \\
\text { derived } \mathrm{HS} \text { enhanced the removal of } \mathrm{Zn}, \mathrm{Cu} \text {, and } \mathrm{Cd}\end{array}$ & Olds et al, 2013[15] \\
\hline $\begin{array}{l}\text { Humin and humic acids } \\
\text { isolated from a forest soil in } \\
\text { northeast China }\end{array}$ & $\begin{array}{l}\text { adsorption and desorption } \\
\text { properties of } \mathrm{Cu}(\mathrm{II})\end{array}$ & $\begin{array}{l}\text { humin has a lower adsorption capacity and higher } \\
\text { adsorption reversibility for } \mathrm{Cu}(\mathrm{II}) \text {. It plays an important } \\
\text { role in controlling the fate, transport and bioavailability } \\
\text { of } \mathrm{Cu} \text { (II) in the environment. }\end{array}$ & Zhang et al, 2013[16] \\
\hline $\begin{array}{l}\text { Kaolinite and hematite in } \\
\text { the absence and presence of } \\
\text { humic acid }\end{array}$ & $\mathrm{Cu}(\mathrm{II})$ & $\begin{array}{l}\text { The rate and the amount of adsorption in the absence or } \\
\text { the presence of humic acid increased with decreasing } \\
\text { ionic strength, increasing } \mathrm{pH} \text { and in the presence of the } \\
\text { background electrolyte } \mathrm{K}+\text { rather than } \\
\mathrm{Ca} 2+\text {. Humic acid enhanced the rate and the amount } \\
\text { of adsorption }\end{array}$ & Komy et al, 2014[17] \\
\hline $\begin{array}{l}\text { Beysehir and } \\
\text { Ermenek lignite IHA }\end{array}$ & $\mathrm{Cr}, \mathrm{Fe}, \mathrm{Mn}, \mathrm{Zn}, \mathrm{Cu}$ & $\begin{array}{l}\text { Cr:0.49-0.35; Fe:0.25-0.19 } \\
\text { Mn:0.24-0.31; Zn:0.19-0.22 } \\
\text { Cu:0.09-0.12 meq/g }\end{array}$ & this study \\
\hline
\end{tabular}

TABLE II: DBP COMPOUNDS AND HEALTH EFFECTS [27], AND MODIFIED FROM [29]

\begin{tabular}{|c|c|c|c|c|c|}
\hline A. $\quad D B P$ & $\begin{array}{c}\text { Cancer } \\
\text { Class }\end{array}$ & $B$. & Group & Classification & Description \\
\hline Chloroform & B2 & \multirow{4}{*}{\multicolumn{2}{|c|}{ A }} & \multirow{4}{*}{ Carcinogenic for human } & \multirow{4}{*}{$\begin{array}{l}\text { Epidemiologic studies proved that they are absolutely cause } \\
\text { cancer upon exposure }\end{array}$} \\
\hline Bromodichlorometane & $\mathrm{B} 2$ & & & & \\
\hline Dibromochlorometane & $\mathrm{C}$ & & & & \\
\hline Bromoform & $\mathrm{B} 2$ & & & & \\
\hline Dichloroacetic acid & B2 & \multirow{4}{*}{\multicolumn{2}{|c|}{ B }} & \multirow{4}{*}{$\begin{array}{l}\text { Potentially carcinogenic } \\
\text { for human }\end{array}$} & \multirow{4}{*}{$\begin{array}{l}\text { Limited effects according to epidemiologic studies (B1) } \\
\text { and/or sufficiently effective according to animal } \\
\text { experiments (B2) }\end{array}$} \\
\hline Trichloroacetic acid & $\mathrm{C}$ & & & & \\
\hline Dichloroacetonitril & $\mathrm{C}$ & & & & \\
\hline Dibromoacetonitril & $\mathrm{C}$ & & & & \\
\hline 2 - Chlorophenol & $\mathrm{D}$ & \multirow{3}{*}{\multicolumn{2}{|c|}{$\mathrm{C}$}} & \multirow{3}{*}{$\begin{array}{l}\text { Possibly carcinogenic for } \\
\text { human }\end{array}$} & \multirow{3}{*}{$\begin{array}{l}\text { Limited effects were proved by animal experiments but } \\
\text { human effects are unknown }\end{array}$} \\
\hline 2,4-Dichlorophenol & $\mathrm{D}$ & & & & \\
\hline 2,4,6 - Trichlorophenol & $\mathrm{B} 2$ & & & & \\
\hline Chloral hydrate & $\mathrm{C}$ & \multirow{2}{*}{\multicolumn{2}{|c|}{$\mathrm{D}$}} & \multirow{2}{*}{ Not classified } & \multirow{2}{*}{ Carcinogenci effects for human and animals are unknown } \\
\hline Formaldehite & B1 & & & & \\
\hline Chlorite & $\mathrm{D}$ & \multirow{3}{*}{\multicolumn{2}{|c|}{$\mathrm{E}$}} & \multirow{3}{*}{$\begin{array}{l}\text { Not carcinogenic for } \\
\text { human }\end{array}$} & \multirow{3}{*}{$\begin{array}{l}\text { Not carcinogenic as a result of two differnt animal tests or } \\
\text { epidemiologic and animal tests }\end{array}$} \\
\hline Bromate & B2 & & & & \\
\hline Chlorine dioxide & D & & & & \\
\hline
\end{tabular}

\section{CONCLUSION}

In this study, various aspects of humic substances were investigated. In the first aspect, performance of IHAs as adsorbent were presented. Although IHA samples have not been highly successful to remove metals, still there have been adsorption capacities obtained as 35-49 meq/100g for $\mathrm{Cr}$, 19-25 meq/100g for Fe, 24-31 meq/100g for $\mathrm{Mn}$; $19-22$ 
meq/100g for $\mathrm{Zn}$, and 9-12 meq/100g for $\mathrm{Cu}$. Performance of the two studied IHAs at COD and color removal from waters were higher as 2040-2270 mg/g for COD and 90-144 Pt-Co/g for color.

In the second aspect, three alternative mechanisms that humic substances bind metals were described. Formation of non-adsorbable metal-humic acid complexes; direct binding of humic acid onto adsorbent surface, blocking the adsorption sites on the surface and reducing metal adsorption; and third, forming a bridge between metal and the adsorbent surface, and so increasing the adsorption performance.

As the final aspect, the two common types of DBP's are THM and HAA compounds, they have serious adverse effects on human and environmental health such as cancer as a result of bioaccumulation. Maximum contaminant level (MCL) for total THM concentrations was decreased from 100 to $80 \mu \mathrm{g} / \mathrm{L}$ by USEPA. For HAA compounds, MCL was set as $60 \mu \mathrm{g} / \mathrm{L}$. Their cancer risks are critical and treatment systems need to be modified to prevent such risks.

Humic substances may either helps to keep the environment, or be the cause of destruction of the life. It depends upon the form, structure, place and the interaction of the substance with its environment. Human have ability to control their potential hazards, and have ability to take their advantages.

\section{REFERENCES}

[1] B. S. Xing, J. D. Liu, X. B. Liu, and X. Z. Han, "Extraction and characterization of humic acids and humin fractions from a black soil of China," Pedosphere, vol. 15, no. 1, pp. 1-8, 2005.

[2] G. L. Li and S. Q. Wei, "The characteristic of adsorption and desorption of humic acid on copper," Ecology and Environment, vol. 12, no. 1, pp. 4-7, 2003.

[3] Z. Gua, L. Evansc, H. Guo et al., "Effects of organic acids on adsorption of lead onto montmorillonite, goethite and humic acid," Environmental Pollution, vol. 121, pp. 469-475, 2003.

[4] A. K. Pandey, S. D. Pandey, U. V. Misra, and P. N. Viswanathan, "Role of free radicals in the binding of organochlorine pesticides and heavy metals with humic acid," The Science of the Total Environment, vol. 231, pp. 125-133, 1999.

[5] B. Eyheraguibel, "Caracterisation des substances humiques biomimetiques: Effets sur les vegetaux,” Ph.D Thesis, Institut National Polytechnique de Toulouse, 2004.

[6] E. Tarlan and G. Ahmetli, "Fe(II) Adsorption onto natural polymers derived from low-grade lignites," Journal of Applied Polymer Science, vol. 105, pp. 3146-3152, 2007.

[7] S. E. Hrudey, "Chlorination disinfection byproducts, public health risk tradeoffs and me," Water Research, vol. 43, pp. 2057-2092, 2009.

[8] M. Fooladvand, B. Ramavandi, K. Zandi, and M. Ardestani, "Investigation of trihalomethanes formation potential in Karoon River water," Iran Environ Monit Assess, vol. 178, pp. 63-71, 2011.

[9] G. Ahmetli, E. Yel, H. Deveci, Y. Bravo, and Z. Bravo, "Investigation of $\mathrm{Pb}$ (II) adsorption onto natural and synthetic polymers," Journal of Applied Polymer Sci., vol. 125, pp. 716-724, 2012.

[10] K. Murakami, T. Yamada, K. Fuda, T. Matsunga, and Y. Nishiyama, "The cation exchange properties of the heat-treated Australian brown coal in the water-organic compounds mixed solutions," Fuel, vol. 76, no. 12 , pp. 1085-1090, 1997.

[11] B. Manunza, S. Deiana, V. Maddau, C. Gessa, and R. Seeber, "Stability constants of metal-humate complexes: Titration data analyzed by bimodal gaussian distribution," Soil Sci. Soc. Am. J., vol. 59, pp. 1570, 1995.

[12] L. Madronova, J. Kozler, J. Cezikova, J. Novak, and P. Janos, "Humic acids from coal of the North-Bohemia coal field III. Metal-binding properties of humic acids - measurements in a column arrangement," Reactive \& Functional Polymers, vol. 47, pp.119-123, 2001.
[13] H. Martyniuk and J. Wieckowska, "Adsorption of metal ions on humic acids extracted from brown coals," Fuel Processing Technology, vol. 84, pp. 23-36, 2003.

[14] Q. Wang, S. Wei, Y. Huang, and J. Zhang, "Characteristics of isothermal adsorption and desorption of aluminum ion to/from humic acids," Journal of Environmental Sciences, vol. 20, pp. 579-584, 2008

[15] W. E. Olds, D. C. W. Tsang, and P. Weber, "Acid mine drainage treatment assisted by lignite-derived humic substances," Water Air Soil Pollut, vol. 224, pp. 1521-1532, 2013.

[16] J. Zhang, S. Wang, Q. Wang, N. Wang, C. Li, and L. Wang, "First determination of $\mathrm{Cu}$ adsorption on soil humin," Environ. Chem. Lett., vol. 11, pp. 41-46, 2013.

[17] Z. R. Komy, A. M. Shaker, S. E. M. Heggy, and M. E. A. El-Sayed, "Kinetic study for copper adsorption onto soil minerals in the absence and presence of humic acid," Chemosphere, vol. 99, pp. 117-124, 2014.

[18] C. H. Lai, C. Y. Chen, B. L. Wei, and S. H. Yeh, "Cadmium adsorption on goethite-coated sand in the presence of humic acid," Water Research, vol. 36, pp. 4943-4950, 2002.

[19] A. P. Davis and V. Bhatnagar, "Adsorption of cadmium and humic acid onto hematite," Chemosphere, vol. 30, pp. 243-56, 1995.

[20] P. Wu, Q. Zhang, Y. Dai, N. Zhu, Z. Dang, P. Li, J. Wu, and X. Wang, "Adsorption of $\mathrm{Cu}(\mathrm{II}), \mathrm{Cd}(\mathrm{II})$ and $\mathrm{Cr}(\mathrm{III})$ ions from aqueous solutions on humic acid modified Ca-montmorillonite," Geoderma, vol. 164, pp. 215-219, 2011.

[21] M. Arias, M. T. Barral, and J. C. Mejuto, "Enhancement of copper and cadmium adsorption on kaolin by the presence of humic acids," Chemosphere, vol. 48, pp. 1081-1088, 2002.

[22] P. C. Singer, "Control of disinfection by-products in drinking water," $J$. Environ. Engin., vol. 120, pp. 727-744, 1994.

[23] S. K. Golfinopoulos, N. K. Xylourgidis, M. N. Kostopoulou, and T. D. Lekkas, "Use of a multiple regression model for predicting trihalomethane formation," Water Res., vol. 32, pp. 2821-2829, 1998.

[24] A. D. Nikolaou, K. Spyros, T. D. Golfinopoulos, D. Lekkas, and M. N. Kostopoulou, "DBP Levels in chlorinated drinking water: Effect of humic substances," Environmental Monitoring and Assessment, vol. 93, pp. 301-319, 2004

[25] S. C. Lee, H. Guo, S. M. J. Lam, and S. L. A. Lau, "Multipathway risk assessment on disinfection by-products of drinking water in Hong Kong," Environmental Research, vol. 94, pp. 47-56, 2004.

[26] J. K. Fawell, "The risks of DBPs in perspective, disinfection by-products in drinking water," Current Issues, pp. 157-164, 1999.

[27] EPA, Controlling Disinfection By-Products and Microbial Contaminants in Drinking Water, Office of Research and Development, Washington DC, 2001

[28] W. Wang, B. Ye, L. Yang, and Y. Li, and Y. Wang, "Risk assessment on disinfection by-products of drinking water sources and disinfection processes," Environment International, vol. 33, pp. 219-225, 2007.

[29] S. Kucukcongar, "Effects of Natural Organic Matter (NOM) on disinfection by products formation," PhD Dissertation, Environmental Eng. Dept., Selcuk Univ., Konya, Turkey, 2009.

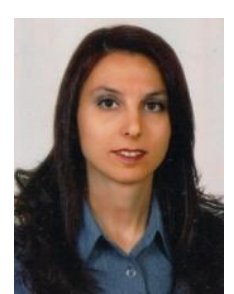

Esra Yel is an environmental engineer graduated from METU-Ankara, Turkey. She has been working as an instructor in the Selcuk University, Environmental Engineering Department since 1992. Her main experiences are in water and wastewater treatment technologies and system design. Besides educational activities, she has been performed various lab-scale research projects about biological treatment with bacteria and algae), oxidative treatment (UV and peroxide oxidation), cyanide and cyanide complexes treatment, disinfection by-products, plastic wastes thermochemical recycling, polymeric substances in adsorption and ion-exchange.

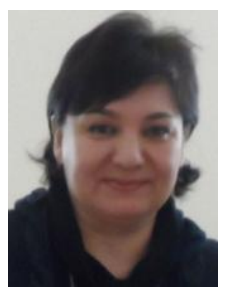

Gulnare Ahmetli is a polymer chemist graduated from Azerbaijan Sciences Academy, Baku, Azerbaijan. She has been working as an instructor in the Selcuk University, Chemical Engineering Department since 1996. Her main experiences are polymers and chemical technologies. Besides educational activities, she has been performed various lab-scale research projects about polymeric materials synthesis and utilization in various areas, composite material researches, polymeric substances in adsorption and ion-exchange. 